\title{
Smokers' reactions to cigarette package warnings with graphic imagery and with only text: A comparison between Mexico and Canada
}

\author{
James F Thrasher, PhD, (1,2) David Hammond, PhD, (3) Geoffrey T Fong, PhD, ${ }^{(4)}$ \\ Edna Arillo-Santillán, M en C. ${ }^{(2)}$
}

\section{Thrasher JF, Hammond D, Fong GT,Arillo-Santillán E. Smokers' reactions to cigarette package warnings with graphic imagery and with only text: \\ A comparison between Mexico and Canada. Salud Publica Mex 2007;49 suppl 2:S233-S240.}

\begin{abstract}
Objective. This comparison of population-based representative samples of adult smokers in Canada $(n=|75|)$ and Mexico $(n=\mid 08 I)$ aimed to determine whether cigarette packages with graphic warning labels in Canada had a stronger impact than the text-only warning labels in Mexico. Materials and Methods. Bivariate and multivariate adjusted models were used in this study. Results. Canadian smokers reported higher warning label salience (i.e., noticing labels \& processing label messages) than Mexican smokers, and warning label salience independently predicted intention to quit. Moreover, Canadians had higher levels of knowledge about smoking-related health outcomes that were included as content on Canadian, but not Mexican, warning labels. Finally, a majority of Mexican smokers want their cigarette packs to contain more information than they currently contain. Discussion. These results are consistent with other studies that indicate that cigarette packages whose warning labels contain prominent graphic imagery are more likely than text-only warning labels to promote smoking-related knowledge and smoking cessation.
\end{abstract}

Thrasher JF, Hammond D, Fong GT,Arillo-Santillán E. Reacciones de los fumadores a las advertencias en la cajetilla de cigarrillos con imágenes gráficas o sólo con textos: una comparación entre México y Canadá. Salud Publica Mex 2007;49 supl 2:S233-S240.

\section{Resumen}

Objetivo. Esta comparación basada en muestras representativas de la población de fumadores adultos de Canadá $(n=|75|)$ y México $(n=|08|)$ pretendió determinar si las cajetillas de cigarrillos con leyendas de advertencia que contienen imágenes gráficas en Canadá tuvieron un impacto más acentuado que las leyendas mexicanas que se basan sólo en textos. Material y métodos. En el presente estudio se usaron modelos bivariados y multivariados. Resultados. Los fumadores canadienses respondieron mucho mejor a las advertencias de la etiqueta (es decir, atención que prestaban a los anuncios de las etiquetas y comprensión del mensaje) que los fumadores mexicanos y fueron influidos por las características de las advertencias independientemente de la intención previa que tuvieran de abandonar el hábito. Más aún, los canadienses tienen grados de conocimiento más altos acerca de las repercusiones en la salud que tiene fumar y que fueron incluidas en las advertencias de las etiquetas canadienses pero no en las mexicanas. Por otro lado, la mayoría de los fumadores mexicanos deseó que las cajetillas de cigarrillos incluyeran más información que la que contienen

(I) Department of Health Promotion, Education \& Behavior, USA.

(2) Department of Tobacco Research, Mexican National Institute of Public Health, Mexico.

(3) Department of Health Studies and Gerontology, University of Waterloo, Canada.

(4) Department of Psychology, University of Waterloo, Canada.

Received on: April 4, 2007 - Accepted on: April 24, 2007

Address reprint request to: $\mathrm{PhD}$, James F.Thrasher. Department of Health Promotion, Education \& Behavior. 800 Sumter Street, Room 215 Columbia, SC 29208, USA E-mail: thrasher@gwm.sc.edu 
Key words: tobacco policy; smoking cessation; cigarette packaging; warning labels; communication; Canada actualmente. Conclusión. Estos resultados son consistentes con los de otros estudios en cuanto a indicar que las cajetillas de cigarrillos cuyas etiquetas incluyen mensajes de advertencia con imágenes gráficas destacadas tienen más probabilidad de promover el conocimiento relativo a las consecuencias del tabaquismo y la cesación del mismo que las advertencias que sólo se basan en textos.

Palabras clave: política contra el tabaco; cesación de fumar; cajetilla de cigarrillos; etiquetas con advertencias; comunicación; Canadá
$\mathrm{T}$ The Framework Convention on Tobacco Control's (FCTC) guiding principle is that "every person should be informed of the health consequences, addictive nature, and mortal threat posed by tobacco consumption and exposure to tobacco smoke." ${ }^{1}$ Indeed, smokers who are more aware of these risks are more motivated to quit smoking. ${ }^{2}$ Warning labels on cigarette packages are meant to communicate such smoking-associated risks. When the tobacco industry bears printing costs, warning labels can be an extremely cost-effective educational intervention, especially when compared to other efforts, such as mass media campaigns. However, to be effective, warning labels should be prominent enough to capture smoker's attention and must stave off the "wear-out" that results from habituation to messages. ${ }^{3}$ For this reason, the FCTC states that warning labels "should be $50 \%$ or more of the principal display areas but shall be no less than $30 \%$ of the principal display areas" and "may be in the form of or use pictures or pictograms."

Research suggests that warning labels with prominent graphic elements are more effective than text-only messages in engaging smokers, promoting quitting, and impeding "wear-out" that results from habituation to messages. ${ }^{4-6}$ Evidence from Brazil suggests that once graphic warnings were implemented there (2002), the number of calls to quit lines advertised on warning labels increased significantly, and two-thirds of smokers reported that the graphic warning labels increased their desire to quit smoking. ${ }^{7}$ In 2000, Canada implemented 16 rotating graphic warning labels that covered $50 \%$ of the front and back sides of cigarette packs (Figure 1). Studies comparing Canadian smokers with smokers in the US, Australia, and the UK have indicated the greater strength of graphic warnings compared to text warnings. For example, in $2002-2.5$ years after the introduction of graphic warning labels in Canada-Canadian smokers were more likely than smokers in the other countries to notice the warning labels, to read or look closely at the labels, and to have reported that a

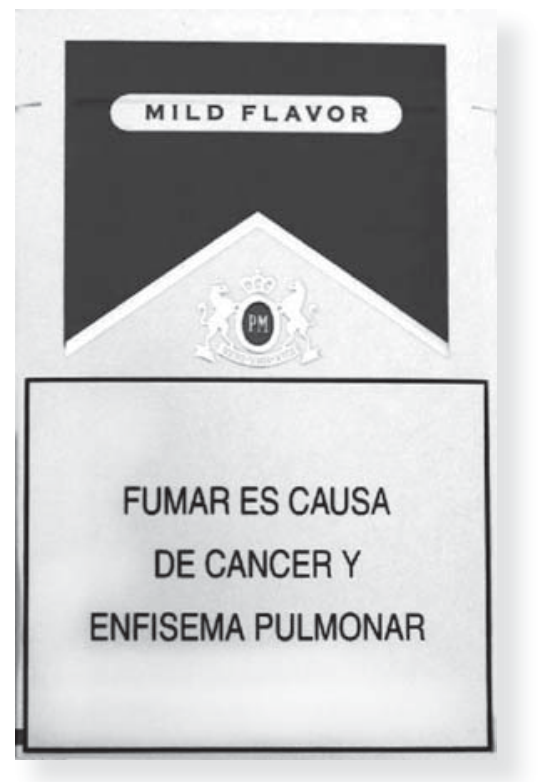

Mexico: $50 \%$ of the back of the package, without specification of the background or contrast with text

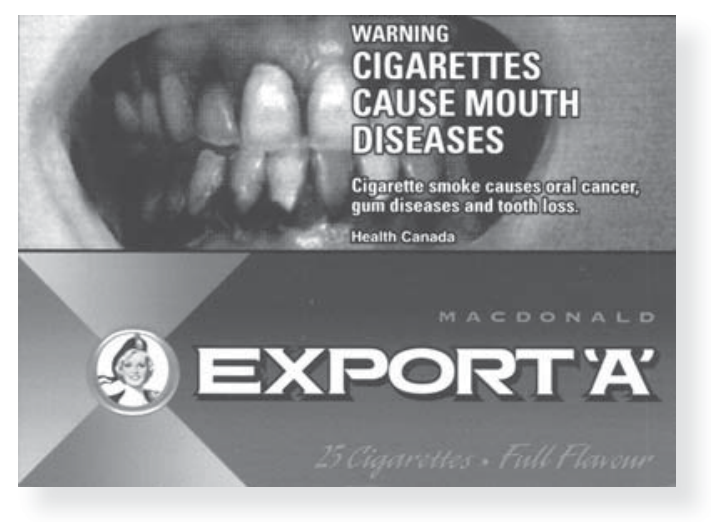

Canada: $50 \%$ of the front and $50 \%$ of the back of the package, with color imagery and graphics that contrast with the background

Figure I. Current cigarette package Warning labels in Canada and Mexico 
warning label had stopped them from having a cigarette. ${ }^{8}$ Follow-up of cohorts of adult smokers in these four Anglo countries indicated that the introduction of larger, bolded text warning labels in the UK (i.e, from $6 \%$ of the front of the package to $30 \%$ of the front and $40 \%$ of the back) increased their being noticed, read, and caused smokers to think about the health risks of smoking. Nevertheless, the Canadian graphic warnings appeared to have stronger, more durable effects over time with regard to making smokers think about smoking-related dangers and about quitting. ${ }^{9}$ These results suggest that prominent warning labels with graphic elements appear to be a particularly powerful means of education and promoting smoking cessation. Furthermore, the use of images to express the consequences of smoking may be a particularly effective educational strategy where a sizeable proportion of the population is not literate and, therefore, unlikely to notice or understand text-based warnings.

The effectiveness of current cigarette labeling practices in Mexico is generally unknown. In 2004, warning labels were increased to $50 \%$ of the backside of cigarette packages, with three rotating messages in the warning label area, while the message "Currently, there are no cigarettes that reduce health risks" (i.e. "Actualmente no existe un cigarro que reduzca los riesgos a la salud") is on the side of every pack. The warning text font is not bolded, is relatively small (12 point, normal helvetica), and there are no warnings on the front of the pack (Figure 1). Only one study has examined Mexican smokers' reactions to current warning labels, using methods from experimental economics to compare the perceived value of a normal pack of Marlboros with a pack that was identical except for its graphic warning label. This study concluded that smokers attributed values that were on average $17 \%$ lower for the pack with the graphic warning than for the pack with the current text-only warning, indicating a significantly reduced demand for the pack with the graphic warning. Moreover, this significantly lower perceived value was found within population subgroups defined by sociodemographics, average daily consumption of cigarettes, history of quit attempts, and levels of perceived smoking risks. ${ }^{10}$ The current study aims to complement this effort by comparing reactions to warning labels across population-based representative samples of adult smokers in Mexico and Canada.

\section{Material and Methods}

Study sample: Data were drawn from the International Tobacco Control Policy Evaluation Project (ITC), an international effort to understand policy impacts, as well as the mechanisms of these impacts, by comparing cohorts of adult smokers in countries with different tobacco policy environments. ${ }^{11,12}$ For the Canadian sample, households with smokers were identified using random digit dialing techniques, with probability of selection proportional to community size. Telephone surveys have been administered to participants each year since 2002, with replenishment from the same sampling frame for those lost to attrition. ${ }^{13}$ For the present analysis, data from the 2005 ITC-Canada survey were used (2006 data were unavailable at the time of analysis).

The ITC-Mexico sample involved a two-stage sampling scheme, with the sampling frame limited to and stratified by four major urban areas (i.e., Mexico City, Guadalajara, Tijuana, and Ciudad Juárez). Data from the 2000 census were used to estimate the number of households within each Basic GeoStatistical Area (i.e. AGEB, in its spanish acronym) and block groups (i.e., manzana) for each city. Within each city, 20 AGEB were randomly selected, with selection probability proportional to the number of households within the AGEB. Proportional sampling methods were used again to select two manzanas within each selected AGEB, with a target of seven interviews per manzana. Households within each selected manzana were visited in random order, with up to four visits on distinct days (two weekend days and two weekdays) and at different times of day. As in ITC-Canada, once contact was made with an adult household member, households were enumerated and eligible smokers identified. Only those who were 18 or older, had smoked at least once in the previous week, and had smoked 100 cigarettes in their lifetimes were eligible to participate in ITC-Mexico. ITCCanada used the same criteria except for including adults who had smoked at least once in the last month, but not in the last week $(n=23)$, and those who had quit smoking since their initial inclusion in the cohort $(n=255)$. These participants were excluded from the current analytic sample. If more than one smoker was identified in a household, then only one was randomly selected for an interview. Cooperation rates with eligible participants were $65.4 \%$ in Canada and $86.1 \%$ in Mexico. The final sample size included 1751 participants from the 2005 ITC-Canada survey and 1081 from the baseline 2006 ITC-Mexico survey.

Measurement: The English language ITC survey was adapted to Mexico using committee translation methods, ${ }^{14}$ cognitive interviewing, ${ }^{15}$ and analysis of pilot data to help ensure adequate comprehension and the equivalence of measures across countries. Standard questions regarding frequency of smoking were used to divide smokers into daily and non-daily smokers. Furthermore, extent of nicotine dependence was estimated using the heaviness of smoking index, a 7-point index that considers both the average daily consumption of cigarettes and the usual amount of time that passes from 
awakening to smoking the first cigarette of the day. ${ }^{16}$ Questions regarding quit attempts and intentions were dichotomized to reflect any attempts at quitting smoking in the past year and any intention to quit smoking in the future, respectively, both of which have been shown to predict future quit status. ${ }^{17,18}$

Questions to assess warning label salience and impact reflect theories regarding stages of message processing:8 1) awareness of the stimulus (i.e. "En el último mes, ¿cuántas veces ha notado las advertencias sobre los daños a la salud en las cajetillas de cigarros?: Nunca, De vez en cuando, Con frecuencia, Con mucha frecuencia"); 2) engagement with its message (i.e. "En el último mes, ¿con qué frecuencia ha le do o ha puesto atención en las advertencias de las cajetillas de cigarros?: Nunca, De vez en cuando, Con frecuencia, Con mucha frecuencia"); 3) depth of processing the dangers of smoking because of the labels (i.e. "Hasta que punto ¿las advertencias en cajetillas le hacen pensar en los daños que causa fumar?: Nada, Poco, Bastante, Mucho"); and 4) depth of processing about quitting because of the labels (i.e. "Hasta que punto ¿las advertencies en cajetillas le hacen pensar en dejar de fumar? Nada, Poco, Bastante, Mucho"). In analyses, these variables were treated in two ways. First, responses were dichotomized by collapsing the two highest categories as well as the two lowest categories. For subsequent bivariate and multivariate analyses to assess relationships with other study variables, participants' responses to all four questions were averaged to create a label salience scale. In the ITC Mexico survey, but not the ITC Canada survey, participants were also asked whether they would like warning labels to contain more information (i.e. " $¿ O p i n a$ que las cajetillas de cigarros deben de tener más, menos, o la misma cantidad de información que la que tienen ahora?").

Study participants in both countries were asked to respond to a series of questions to assess beliefs about the health outcomes associated with smoking. Outcomes addressed in both countries included stroke, impotence, and oral cancer in smokers, as well as lung cancer in non-smokers exposed to cigarette smoke. Canadian warning labels, but not Mexican warning labels, describe each of these outcomes. A four-point index was constructed to indicate extent of knowledge within this domain that is specific to Canadian warning labels. Finally, the survey assessed age, gender, and education. Education level was collapsed into three categories: less than high school; completion of high school or technical school; some college or more.

Analyses: All analyses were conducted using STATA, version 8.0, adjusting for the study design effect and sampling weights so that estimates were representa- tive of their respective sampling frames. Hence, the Canadian data were representative of the country with listed phone numbers, whereas the Mexico data were representative of the four major urban areas where data were collected. Population-level estimates and respective $95 \%$ confidence intervals were generated, by country, for each warning label reaction variable and health knowledge variable. The bivariate and multivariate adjusted relationships with the continuous label salience scale and the health knowledge index were estimated using linear regression models. When the dichotomous quit intention outcome was considered, logistic regression models were estimated.

\section{Results}

The study populations from each country differed with regard to sociodemographics and smoking profiles (Table I). The majority of the Canada sample was female $(58 \%)$, whereas males comprised the majority of the Mexico sample (61\%). The Canada sample was slightly older than the Mexican sample (mean age $=$ 43.8 vs. 39.1 ) and more highly educated, with $25 \%$ of Canadians and $18 \%$ of Mexicans having at least some college. Educational differences were starker when comparing the percentage of people with less than a high school degree (53\% in Mexico vs. 16\% in Canada). Very few smokers in the Canadian sample smoked less than daily (3\%), whereas about one fifth of those in the Mexican sample did (22\%). Reported quit attempts in the previous year were more than twice as high among Canadian smokers than among Mexican smokers (36\% vs. $17 \%$, respectively), and intention to quit was also higher among Canadians ( $76 \%$ vs. $51 \%$ ).

Estimates associated with the dichotomous warning label salience variables were derived for each country, and differences were assessed using chisquare tests. Label salience was significantly higher in Canada than Mexico when considering the frequency of noticing warning labels and for the two depth-ofprocessing variables, which focused on the label making participants think about the dangers of smoking and about quitting smoking (Figure 2). However, the prevalence of smokers who frequently read warning labels was not statistically different across the two countries. These four items had generally equivalent, good inter-item reliability for both countries (Canada $\alpha=0.75$; Mexico $\alpha=0.74$ ) and, hence, were averaged to create a scale (range 0-3). The unadjusted mean for this scale was higher for the Canada sample than for the Mexico sample (1.27 vs. $1.13 ; \mathrm{p}=0.002$ ).

Bivariate and multivariate models were estimated, regressing the label salience scale on sociodemographics, 
Table I

Sample Characteristics by country

\begin{tabular}{|c|c|c|c|}
\hline & & & \\
\hline & & Mexico & Canada \\
\hline & & $(n=108 I)$ & $(n=1731)$ \\
\hline Gender & & $\%$ & $\%$ \\
\hline & female & $39(422)$ & $58(1 \mid 70)$ \\
\hline & male & 61 (658) & $42(859)$ \\
\hline Age & & & \\
\hline & $18-24$ & $16(170)$ & $9(164)$ \\
\hline & $25-39$ & $40(430)$ & $28(492)$ \\
\hline & $\overline{40-54}$ & 31 (335) & $4 I(726)$ \\
\hline & $55+$ & $13(143)$ & 21 (369) \\
\hline
\end{tabular}

Education

\begin{tabular}{|c|c|c|c|}
\hline & $<$ High School & $53(572)$ & $16(288)$ \\
\hline & Tech or High School & $29(3 \mathrm{II})$ & $59(1027)$ \\
\hline & College+ & $18(190)$ & $25(432)$ \\
\hline \multirow[t]{2}{*}{ Smoking status } & $<$ daily & $22(233)$ & $3(59)$ \\
\hline & Daily & $78(84 I)$ & 97 (I70I) \\
\hline \multirow[t]{2}{*}{ Tried quitting in last year } & No & $83(899)$ & $64(1,116)$ \\
\hline & Yes & $17(179)$ & $36(635)$ \\
\hline \multirow[t]{2}{*}{ Some intention to quit } & No & $49(495)$ & $24(4 I I)$ \\
\hline & Yes & $5 \mathrm{II}(509)$ & $76(1322)$ \\
\hline
\end{tabular}

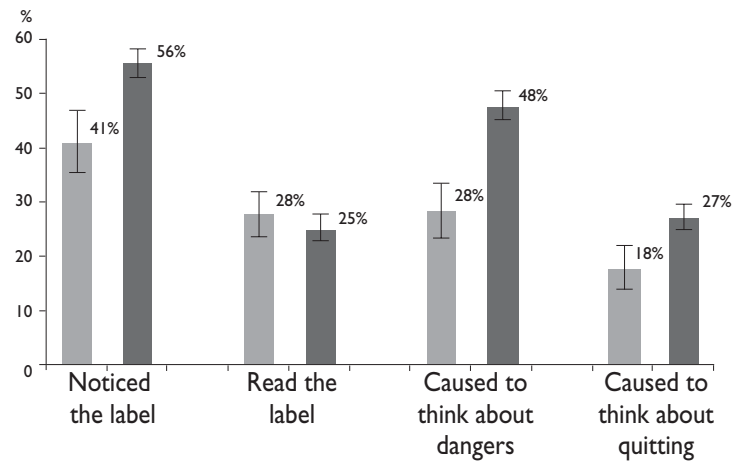

* "frequently" or "very frequently"

Figure 2. Warning label salience in the last month, * BY COUNTRY smoking variables, and a dummy coded country variable, in order to determine country differences in label salience both before and after statistical adjustment for differences across the two samples (Table II). Bivariate coefficients suggested that higher education and being female were associated with greater label salience; however, these associations were not statistically significant in the mulitivariate model. Having attempted to quit smoking in the previous year, being less addicted to smoking, and being in the Canadian sample were all independently associated with greater warning label salience in the multivariate model.

It was hypothesized that knowledge of certain smoking-related health outcomes would be higher in Canada than in Mexico, because these health outcomes were included as content on Canadian warning labels but not on the Mexican labels. Indeed, this was the case when examining the prevalence of knowledge regarding whether smoking causes stroke, impotence, and mouth cancer, but not when assessing knowledge of second-hand smoke causing lung cancer in nonsmokers (Figure 3). When these items were summed to create a health knowledge index (range 0-4), average scores were higher among Canadians than among Mexicans (3.44 vs. $2.79 ; p<0.0001$ ). Bivariate and multivariate models indicated that health knowledge was inversely and independently associated with age and the heaviness of smoking, whereas it was positively associated with education and being from the Canadian sample (Table III). Hence, warning label-specific

Table II

BivARIATE AND MULTIVARIATE MODELS REGRESSING LABEL SALIENCE SCALE ON SOCIODEMOGRAPHICS AND KEY PREDICTORS

\begin{tabular}{lcc}
$\begin{array}{c}\text { Independent } \\
\text { Variables }\end{array}$ & $\begin{array}{c}\text { Bivariate } \\
\text { unadjusted } \\
B(S E)\end{array}$ & $\begin{array}{c}\text { Multivariate } \\
\text { adjusted } \\
B_{\text {adj }}(S E)\end{array}$ \\
\hline Male & $-0.08(0.03)^{*}$ & $-0.06(0.03)$ \\
\hline Age & $0.00(0.00)$ & $0.00(0.00)$ \\
\hline Education & $0.05(0.03)^{*}$ & $0.01(0.03)$ \\
\hline Heaviness of smoking & $-0.01(0.01)$ & $-0.03(0.01)^{*}$ \\
\hline Daily vs. non-daily & $0.09(0.09)$ & $0.05(0.09)$ \\
\hline Tried to quit in last yr & $0.21(0.04)^{\ddagger}$ & $0.17(0.04)^{\ddagger}$ \\
\hline CA vs. MX & $0.14(0.05)^{\S}$ & $0.14(0.05)^{\S}$ \\
$* p<0.05$ & & \\
$\ddagger p<0.000$ I & & \\
$\S p<0.001$ & & \\
\end{tabular}




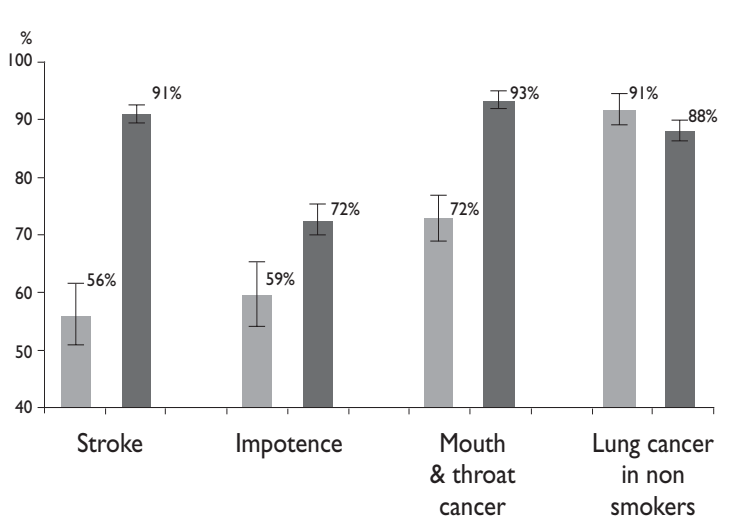

Figure 3. KnOWLedge about smoking outcomes on Canadian Warning labels but not on Mexican Warning LABELS, BY COUNTRY

knowledge appeared higher in the Canadian sample after adjustment for confounding variables.

Next, the relationships between the intention to quit and key study variables, including warning label salience, were examined (Table IV). Bivariate analyses suggested quit intention was associated with being female, being younger, having more education, having tried to quit in the last year, having more knowledge of health outcomes, reporting stronger salience of warning labels, and being in Canada. A logistic multivariate adjusted model was estimated, regressing quit intention on these and the other variables under consideration. Results indicated that education level and health knowledge were no longer statistically significant, but other variables continued to be statistically significant: younger age, less heavy smoking, having tried to quit in the past year, and being in Canada. Of specific interest was the independent association between warning label salience and quit intention.

Finally, we examined the prevalence of adult smokers' desires for more health information on cigarette packs, for which data were available only for the Mexico sample. Prevalence estimates indicated that the majority $(55 \%)$ wanted more information, whereas $42 \%$ were content with the current amount of information.

\section{Discussion}

The results from this study demonstrate a linkage between warning label salience and quit intention, an important predictor of actual cessation behavior. ${ }^{2}$ More-
Table III

BIVARIATE AND MULTIVARIATE MODELS REGRESSING WARNING LABEL-SPECIFIC HEALTH KNOWLEDGE ON SOCIODEMOGRAPHICS AND KEY PREDICTORS

\begin{tabular}{lcc}
$\begin{array}{l}\text { Independent } \\
\text { variables }\end{array}$ & $\begin{array}{c}\text { Bivariate } \\
\text { unadjusted } \\
B(S E)\end{array}$ & $\begin{array}{c}\text { Multivariate } \\
\text { adjusted } \\
B_{\text {adj }}(S E)\end{array}$ \\
\hline Male & $-0.03(0.05)$ & $0.03(0.05)$ \\
\hline Age & $-0.01(0.00)^{*}$ & $-0.01(0.00)^{*}$ \\
\hline Education & $0.31(0.04)^{\ddagger}$ & $0.15(0.04)^{\ddagger}$ \\
\hline Heaviness of smoking & $0.05(0.02)^{\S}$ & $-0.04(0.02)^{\S}$ \\
\hline Daily vs. non-daily & $0.12(0.12)$ & $-0.10(0.12)$ \\
\hline Tried to quit in last yr & $0.19(0.06)^{*}$ & $0.03(0.05)$ \\
\hline CA vs. MX & $0.65(0.07)^{\ddagger}$ & $0.66(0.07)^{\ddagger}$ \\
$* p<0.01$ & & \\
$\ddagger p<0.000$ I & & \\
$\S p<0.05$ & & \\
& &
\end{tabular}

Table IV

BIVARIATE AND MULTIVARIATE MODELS REGRESSING QUIT INTENTION ON SOCIODEMOGRAPHICS AND KEY PREDICTOR VARIABLES

\begin{tabular}{|c|c|c|}
\hline $\begin{array}{l}\text { Independent } \\
\text { variables }\end{array}$ & $\begin{array}{c}\text { Bivariate } \\
\text { unadjusted } \\
B(S E)\end{array}$ & $\begin{array}{c}\text { Multivariate } \\
\text { adjusted } \\
B_{\text {adj }}(S E)\end{array}$ \\
\hline Male & $-0.23(0.09)^{*}$ & $-0.15(0.11)$ \\
\hline Age & $-0.02(0.00)^{\ddagger}$ & $-0.02(0.00)^{* * *}$ \\
\hline Education & $0.40(0.07)^{\ddagger}$ & $0.07(0.10)$ \\
\hline Heaviness of smoking & $0.04(0.03)$ & $-0.09(0.04)^{*}$ \\
\hline Daily vs. non-daily & $0.22(0.19)$ & $-0.28(0.19)$ \\
\hline Tried to quit in last yr & $1.25(0.12)^{\ddagger}$ & $0.90(0.14)^{\ddagger}$ \\
\hline CA vs. MX & $1.03(0.13)^{\ddagger}$ & $\mathrm{I} .17(0.18)^{\ddagger}$ \\
\hline Knowledge & $0.29(0.05)^{\ddagger}$ & $0.07(0.06)$ \\
\hline Label salience & $0.88(0.07)^{\ddagger}$ & $0.77(0.08)^{\ddagger}$ \\
\hline \multicolumn{3}{|l|}{${ }^{*} p<0.05$} \\
\hline \multicolumn{3}{|l|}{$\ddagger p<0.0001$} \\
\hline$\S p<0.001$ & & \\
\hline
\end{tabular}

over, the salience of warning labels on cigarette packages, as well as the knowledge about smoking-related health outcomes that is specific to Canadian warning labels, is stronger in Canada than in Mexico. Furthermore, the lower "wear-out" of graphic warnings is indicated by the difference in salience, in spite of the five years that had passed from warning implementation to the 2005 
ITC-Canada data collection effort, whereas the warning label size increase was only two years prior to data collection in Mexico. Overall, these results are consistent with findings from research comparing reactions to Canadian graphic warnings with reactions to text-only warning labels in other countries. ${ }^{8,9}$ Furthermore, these results complement and strengthen conclusions from experimental research in Mexico, which indicates that graphic warning labels are likely to decrease demand for cigarettes among adult smokers. ${ }^{10}$

Sociodemographic factors were inconsistently associated with key study outcomes. For example, gender was not independently associated with any outcome examined. Not surprisingly, education was independently associated with knowledge about health outcomes, but, somewhat surprisingly, not with quit intention or label salience. Younger age was independently associated with both intention to quit and health knowledge, indicating that different efforts may be needed to target younger than older populations.

Smoking and quitting behavior variables showed a similarly inconsistent relationship to the outcomes of interest. No study outcome was associated with being a daily versus non-daily smoker. However, those with higher levels of nicotine dependence - as measured by the heaviness of smoking index - were less likely to process warning labels, possess knowledge of health outcomes, or intend to quit. The population of nicotine dependent smokers is likely to prove the most difficult to influence, even with warning labels, and may demand extra intervention efforts, such as provision of nicotine replacement therapies. As expected, recent quit attempts predicted both warning label salience and future quit intentions.

A number of weaknesses in our study derive from its cross-sectional nature. It was impossible to determine the temporal sequence of some key study constructs. For example, those who are most interested in quitting may pay more attention to warning labels, rather than labels causing intention to quit. When possible, our models include statistical controls, such as recent quit attempts, to reduce such confounding. Later follow-up of the sample should help clarify temporal precedence in our models. Another issue concerns comparability of the Canadian and Mexican samples. Indeed, the samples differed on most measured variables and may differ in other important ways that we did not assess. For example, the greater health knowledge among Canadian smokers may be accounted for by factors other than the warnings on cigarette packages, such as mass media counteradvertising campaigns. Nevertheless, when we were able to employ statistical controls, our primary conclu- sions regarding the stronger graphic warning labels in Canada did not change. Finally, the different modes of survey administration may have systematically biased our results. ${ }^{19}$ However, if, as we hypothesize, face-toface survey administration in Mexico produced more acquiescence and socially desirable responding than telephone administration in Canada, it is likely that we have underestimated the difference between the two countries. Further research on differential influence of administration modalities across countries and sociocultural contexts should clarify this issue.

In sum, the present study is consistent with other research indicating that prominent warning labels with graphic elements are more likely to promote quitting behavior among smokers than text-only warning labels. As Mexico and other signatories of the Framework Convention on Tobacco Control contemplate implementation of different warning label strategies, the scientific evidence is increasingly clear: graphic warning labels are a powerful, low-cost means of informing consumers about smoking dangers in a manner that mitigates the level of "wear-out" and habituation that occurs with text-only messages. Moreover, the implementation of this policy can respond to the majority of Mexican smokers who, our study suggests, want more information on their cigarette packs. In deciding which labels to implement, policymakers should consider other research on existing graphic warning labels, including which images prompt Mexican smokers to think most about quitting. ${ }^{20}$

\section{Acknowledgements}

This research was supported by the National Cancer Institute of the United States through The University of Illinois at Chicago Cancer Center, Cancer Education and Career Development Program (R25-CA57699) and the Roswell Park Transdisciplinary Tobacco Use Research Center (RO1 CA100362 and P5OCA111236) as well as by the Canadian Institutes of Health Research (57897 and 79551).

\section{References}

I.WHO. Framework Convention on Tobacco Control. Geneva, Switzerland:World Health Organization, Tobacco Free Initiative, 2003. 2. Romer D, Jamieson P.The role of perceived risk in starting and stopping smoking. In: Slovic, ed. Smoking: Risk, perception, and policy.Thousand Oaks, CA: Sage, 2001:65-80.

3. USDHHS. Reducing the health consequences of smoking: 25 years of progress. A report of the Surgeon General. Bethesda, MD: US Department of Health and Human Services, 1989. 
4. Strahan E, White KS, Fong GT, Fabrigar L, Zanna MP, Cameron R. Enhancing the effectiveness of message labels on tobacco packaging: $A$ social psychological perspective. Tobacco Control 2002; 1 : 183-190. 5. Hammond D, Fong GT, MacDonald P, Cameron R, Brown K. Impact of graphic Canadian warning labels on adult smoking behavior. Tobacco Control 2003;12:391-395.

6. O'Hegarty M, Pederson LL, Nelson DE, Mowery P, Gable JM, Wortley P. Reactions of young adult smokers to warning labels on cigarette packages. American Journal of Preventive Medicine 2006;30(6):467-473.

7. Cavalcante TM. Labelling and packaging in Brazil. Geneva, Switzerland: World Health Organization,2003.

8. Hammond D, Fong GT, McNeil A, Borland R, Cummings KM. The effectiveness of cigarette warning labels in informing smokers about the risks of smoking: Findings from the International Tobacco Control (ITC) Four Country Survey. Tobacco Control 2006; I5(Supp 3):iii I9-25. 9. Hammond D, Fong GT, Borland R, Cummings KM, McNeil AD, Driezen P. Text and graphic warnings on cigarette packages: Findings from the International Tobacco Control Four Country Study.Am Prev Med 2007;32(3):210-217.

10.Thrasher JF, Rousu MC, Ocampo-Anaya R, Reynales-Shigematsu LM, Arillo-Santillán E, Hernández-Ávila M. Estimating the impact of graphic warning labels on cigarette packs: The auction method.Addiction under review.

I I. Thrasher JF, Chaloupka F, Hammond D, Fong GT, Borland R, Hastings $\mathrm{G}$, et al. Evaluación de las políticas contra el tabaquismo en países latinoamericanos en la era del Convenio Marco para el Control del Tabaco. Salud Publica Mex 2006;48(Supp I):SI55-SI66.

12. Fong GT, Cummings KM, Borland R, Hastings G. The conceptual framework of the International Tobacco Control Policy Evaluation Project. Tob Control 2006;15(Supp 3):iii3-iiil I.
13.Thompson ME, Fong GT, Hammond D, Boudreau C, Dreizen PR, Hyland A, et al.The methodology of the International Tobacco Control Policy Evaluation Project. Tob Control 2006;15(Supp 3):iii I-iiil 8.

14. Harkness JA. Questionnaire translation. In: Harkness JA,Van de Vijver FJR, Mohler PP, eds. Cross-cultural survey research. Hoboken, Nj:Wiley \& Sons, 2003:35-56.

15. Willis GB. Cognitive interviewing. London: Sage, 2005.

16. Heatherton TF, Koslowski LT, Frecker RC, Rickert WS, Robinson J. Measuring the heaviness of smoking using self-reported time to the first cigarette of the day and number of cigarettes smoked per day. $\mathrm{Br} J$ Addict 1989;84:79|-800

17. Hammond D, Fong GT, Zanna MP,Thrasher JF, Borland R. Tobacco denormalization, anti-industry beliefs, and cessation behavior among smokers from four countries. Am J Prev Med 2006;31 (3):225-232.

18. Hyland A, Laux F, Higbee C, Hastings G, Ross H, Chaloupka FJ, et al, Cummings KM. Cigarette purchase patterns in four countries and its relationship with cessation: Findings from the International Tobacco Control Policy Evaluation Survey. Tobacco Control 2006; 15(Supp 3): iii59-64.

19. Harkness JA, Van de Vijver FJR, Mohler PP, eds. Cross-cultural survey methods. Hoboken, NJ:Wiley, 2003.

20.Thrasher JF,Allen B,Anaya-Ocampo R, Reynales LM, Lazcano-Ponce EC, Hernández-Avila M. Análisis del impacto en fumadores Mexicanos de los avisos gráficos en las cajetillas de cigarros. Salud Publica Mex 2006;48: S65-S75. 